\title{
Introduction
}

The law's relationship with medicine has become a highly publicised affair. Rarely a day passes without media coverage of some new controversy surrounding medical practice, or medical ethics. Cases relating to the rights and responsibilities of doctors and patients feature regularly in the Law Reports. The medical profession finds itself in the limelight. One day the doctor is hailed as a saviour. The next she is condemned as authoritarian or uncaring. Advances in medical science, extending life at one end and bringing new hope to the childless at the other, have given rise to intricate problems of law and ethics. At every level of medical practice, law plays a role. Doctors cannot escape the reach of the law. For many medical practitioners, the rise in the number of malpractice claims is their main concern. Despite legislation designed to tackle a perceived 'compensation culture' doctors still fear an epidemic of US proportions. Notwithstanding the 'duty of candour', some doctors refuse to risk an apology or even to explain what went wrong lest their careers and reputations suffer should the patient choose to litigate. Patients still find the pursuit of any grievance frustrating. In 2016, people also seek a greater say in their own treatment, and in doing so have the backing of the Supreme Court in Montgomery $v$ Lanarkshire Health Board ${ }^{1}$ Patients are no longer prepared to be patient. The Supreme Court noted that not only are 'patients now widely regarded as persons holding rights' but are also 'widely treated as consumers exercising choices'. At the same time, how far patients who claim rights are also subject to responsibilities is increasingly debated.

It is not only the narrow question of our own health needs that concerns people today. Many of the recent scientific developments are controversial. Research on embryos, 'saviour siblings', human cloning, mitochondrial treatment - all excite controversy. Older controversies about abortion, organ donation and assisted dying get no less difficult with time. The purpose of this book is to examine how medical practice is regulated, to analyse the rights and responsibilities of doctors and patients, to look at the provision of compensation for medical wrongdoing or error, and to explore the framework of legal rules governing those delicate questions of life and death when medicine, morals and the law overlap. It is easy to perceive law's relationship with medicine as one of conflict, mirroring conflict between doctors and their patients. We 
suggest that this is a 'false' conflict. What the medical profession, patients and the public have a need for are:

(1) that the medical profession be properly regulated;

(2) that where possible, the rights and obligations of patients, doctors and other health professionals are clearly defined;

(3) that there is an adequate, fair and rational system of compensation for patients suffering injury;

(4) that there are effective means of investigating medical accidents and errors;

(5) that the law (together with professional guidelines) offers comprehensive guidance on those areas of medical practice of moral and ethical sensitivity.

\section{Sources of law}

In contrast to most European countries, the law of England is not neatly encapsulated in any Code. The task of the non-lawyer seeking to establish her rights, or ascertain his duties is far from easy. The law relating to medical practice is to be discovered from a variety of sources. Parliament has enacted a number of statutes governing medical practice. The regulation of medical practice and the disciplining of the defaulting doctor have traditionally been entrusted by Act of Parliament to the General Medical Council (GMC), by virtue of the Medical Act 1983: an Act that has been substantially amended. The organisation of the health service has been governed by countless statutes on the National Health Service (NHS), consolidated in the National Health Service Act 2006, and subject to major reform in the Health and Social Care Act 2012. The Medicines Act 1968 (also heavily amended) is concerned with the safety of drugs. A number of other Acts of Parliament, such as the Abortion Act 1967 and the Human Fertilisation and Embryology Act 1990 (as amended), the Human Tissue Act 2004 and the Mental Capacity Act 2005, are crucially relevant to questions about medicine, patients and the law. An Act of Parliament can create only a general framework of legal rules. Acts of Parliament, therefore, commonly empower government ministers to make subsidiary regulations known as statutory instruments. These regulations may determine crucial questions. For example, most of the duties of general practitioners within the NHS are dealt with by regulations and not by Act of Parliament.

It is impossible today to understand the legal rules governing the practice of medicine without reference to European law. In matters within the jurisdiction of the Treaty of Rome and subsequent treaties, notably the Treaty of Amsterdam, the European Union is empowered to make laws affecting all Member States. This may be by way of regulations which immediately and directly become law in the United Kingdom, or by way of directives which oblige the United Kingdom government to introduce an appropriate Act of Parliament to give effect to the directive. In 1985, a Community directive on liability for unsafe products resulted in the Consumer Protection Act 1987 which, as we shall see in Chapter 10, introduced strict liability for defective 
drugs. The Data Protection Directive, considered in Chapter 4, will soon be replaced by a Data Protection Regulation, likely to come into force in 2018. Similarly, the Clinical Trial Regulation 2014 replaces the 2001 Clinical Trials Directive, which obliged the United Kingdom to introduce reforms of the law governing medical research. New scientific innovations and pressure to facilitate medical research provide strong incentives for reform. Regulatory harmonisation reflects an increasingly global research environment. Provisions of the European Union treaties themselves may be invoked to make a case for greater rights for patients. This is how Diane Blood won her case to be allowed to be inseminated with her dead husband's sperm abroad.

The European Union must not be confused with the European Convention on Human Rights. That Convention is a separate treaty to which the United Kingdom is a party. The Convention seeks to establish the rights of the individual and directly addresses questions such as rights to life, to privacy, and to found a family. The Human Rights Act 1998 renders rights granted by the Convention enforceable against public authorities in the United Kingdom. Domestic courts must take into account the jurisprudence of the European Court of Human Rights. As we shall see, the Act has transformed areas of medical law and, as a living instrument, that potential has not diminished with time. If the Conservative government repeals the Human Rights Act 1998, the Convention will remain relevant and any change to medical law resulting from repeal of the 1998 Act is likely to be gradual and incremental.

Conventions, statutes and statutory regulations alone, be they UK or European legislation, by no means paint the whole picture of English medical law. Much of English law remains judge-made; the common law of England. Decisions, judgments handed down by the courts, form precedents for determining later disputes and define the rights and duties of doctors and patients in areas untouched by statute. The common law largely governs compensation for medical accidents, the patient's right to determine her own treatment, parents' rights to control medical treatment of their children and, as we shall see, several other vital matters.

We deal with English law. The common law is not confined to England. Decisions of courts in the USA, Canada and elsewhere are mentioned from time to time. Such judgments do not bind an English court. They can be useful as examples, or warnings, showing us how the same basic principles of law have developed elsewhere. Finally it must be remembered that for the lawyer, Scotland counts as a foreign country. Scotland maintains its own independent legal system and, post-devolution, enjoys the power to legislate independently on most issues relating to medical care. Scotland has, for example, enacted its own Human Tissue (Scotland) Act 2006. On many of the questions dealt with in this book, English and Scots law coincide. Occasionally, the law in England and Scotland diverges. We confine ourselves in general to stating the law as it applies in England and Wales, noting that the Welsh Assembly has gained increased powers to legislate independently of the Westminster Parliament. Notably Wales has now enacted its own Human Transplantation (Wales) Act 2013 which entered into force in December 2015 and provides for an opt-out system for cadaver organ donation in Wales. The problems of law 
and medicine addressed in this book are common to the United Kingdom as a whole and well beyond the shores of this country. We hope that the discussion of how the law in England responds to the challenges of modern medicine is instructive to readers outside the United Kingdom and prompts productive comparisons of how different jurisdictions address similar problems.

\section{Part I}

Part I of this book begins by seeking to examine the overall framework of medicine today. How does the law seek to ensure that patients are treated by competent, qualified doctors practising ethical medicine? Does the GMC, which has regulated the medical profession since 1858, meet patients' needs in 2016? What rights do we enjoy in the context of healthcare and how has the Human Rights Act affected medical law? Law can, at best, only set basic standards of behaviour. So we explore some of the ethical principles and dilemmas in modern medicine. Then in the final chapter of Part I, we examine that critical component of any doctor-patient relationship, the necessity for trust and confidence. Can we be assured that our doctors will respect our privacy so that we can feel confident enough to be wholly frank with them? In what exceptional circumstances should that duty of confidence be breached to fulfil some more pressing responsibility to others?

\section{Part II}

In Part II, we examine what remedies the law affords a patient dissatisfied with the medical care which he or she has received. A patient may feel that he has not been fully consulted or properly counselled about the nature and risks of treatment. He may have agreed to treatment and ended up worse, not better. Consequently the patient may seek compensation from the courts. Or he may simply want an investigation of what went wrong, and to ensure that his experience is not suffered by others. It is the rise in litigation that has caused so much anxiety among doctors.

The law relating to medical errors, often described as medical malpractice, operates on two basic principles. (1) The patient must agree to treatment. (2) Treatment must be carried out with proper skill and care on the part of all the members of the medical profession involved. Any doctor who operated on or injected, or even touched, an adult patient against her will might commit a battery, a trespass against the patient's person. A doctor who was shown to have exercised inadequate care of his patient, to have fallen below the required standard of competence, would be liable to compensate the patient for any harm he caused her in the tort of negligence. In short, to obtain compensation, the patient must show that the doctor was at fault. And if she sues for negligence, she must show that the doctor's 'fault' caused her injury. Three overwhelming problems are inherent in these two simple statements.

First, how do courts staffed by lawyer-judges determine when a doctor is at fault? We shall see that the judges in England used to defer largely to the views of the doctors. Recent case law suggests judges are now more ready to scrutinise medical practice. Establishing what constitutes good practice will 
still cause the court some difficulty. The courts remain dependent on expert evidence and a clash of eminent medical opinions is not unusual.

Second, as liability, and the patient's right to compensation, is dependent on a finding of fault, doctors naturally feel that a judgment against them is a body blow to their career and their reputation. Yet a moment's reflection will remind the reader of all the mistakes she has made in her own job. A solicitor overlooking a vital piece of advice from a conference with a client can telephone the client and put things right when he has a chance to check what he has done. A carpenter can have a second go at fixing a door or a cupboard. An overtired, overstrained doctor may commit a momentary error which is irreversible. He is still a good doctor despite one mistake.

Finally, the doctor's fault must be shown to have caused the patient harm. In general, whether a patient is treated within the NHS or privately, the doctor only undertakes to do his best. He does not guarantee a cure. The patient will have a legal remedy only if he can show that the doctor's carelessness or lack of skill caused him injury that he would not otherwise have suffered. So if you contract an infection and are prescribed antibiotics which a competent doctor should have appreciated were inappropriate for you or your condition, you can sue the doctor only if you can show either: (1) that the antibiotic prescribed caused you harm unrelated to your original sickness, for example, brought you out in a violent allergy; or (2) that the absence of appropriate treatment significantly delayed your recovery. And in both cases you must prove that had the doctor acted properly, the harm would have been avoided.

We shall see therefore that the law is a remedy only for more specific and serious grievances against a doctor. It is in any case an expensive and unwieldy weapon. Many patients have complaints, particularly about hospitals, which do not amount to actionable negligence. They complain about being kept waiting, inadequate visiting hours, or rudeness on the part of NHS staff. We shall look in Part II at extra-legal methods of pursuing complaints against a hospital or a doctor, and we consider whether the whole system for compensating medical errors should be replaced by a no-fault compensation scheme. Nor do we limit our examination to faults alleged against medical practitioners. Many medical mishaps arise from the dangers inherent in certain drugs. We consider the liability of the drug companies and attempts by government to ensure that available medicines are safe.

Finally, we should say a word about legal 'language' today. The person who initiates a legal action, for example, the patient suing a doctor for battery or negligence, used to be referred to as the plaintiff. When Lord Woolf recommended radical reforms of the civil justice system, some of which are discussed in Chapter 8, he also proposed that old-fashioned language should be changed into plain English. So, today, the patient bringing a claim against a doctor is simply called the claimant. Where we discuss cases decided before 1999, we use the old term plaintiff. Defendants, thankfully, remain just that, defendants. 


\section{Part III}

Parts I and II of this book focus on the relationship between doctors and patients, both the framework of that relationship and how the law deals with conflict when a patient is dissatisfied with the care that he has received. Part III looks at the dramatic questions in medical law where what is at stake is not only what an individual patient may be entitled to, but also what society should allow. The range of questions addressed is broad. Others are omitted simply on grounds of space. We consider whether parents who find themselves with an unplanned child after receipt of negligent medical advice or treatment, should receive compensation to meet the cost of raising that child. What duties are owed to an unborn child, and should pregnant women continue to enjoy legal immunity from liability to their future children? We venture into the troubled waters of the reproductive technologies, seeking to explain and analyse the law governing such matters as the creation of 'saviour siblings', human cloning, hybrid embryos. We also attempt to address practical questions - how to define parental status, what happens when surrogacy arrangements go wrong, and access to information about gamete donors. Medical research, transplantation and the especial problems around the medical care of children are addressed. We end (appropriately) by examining laws relating to the end of life, and debates about assisted dying.

\section{Law matters}

Medical law has altered beyond recognition in the nearly thirty years since the first edition of this book. No one who reads a newspaper or watches television can be unaware of the sorts of questions which we address. On an almost weekly basis, new initiatives or new laws are proposed. Sometimes it seems as though the dizzying pace of reform reflects little thought about the whole picture. More attention is paid to policy and ethical debate than law. There is insufficient rigorous analysis of what the limits of the law's remit should be. One set of lawyers, doctors and patients groups address the adequacy (or inadequacy) of malpractice litigation. Ethicists, journalists and legal theorists join doctors and theologians in debating the grand moral dilemmas of medicine. Lay people tend not to get much of a chance to have their say until some controversy breaks, such as the scandals around poor standards of care at Mid Staffordshire Foundation Trust. For all these reasons, this book seeks to concentrate more on law than ethics as such, and to attempt to locate our discussions of the law in a practical context. We hope that we can dispel the myth that law is 'boring'. We hope that our discussion may cast some light on what the role of the law should be in the context of modern medicine. 